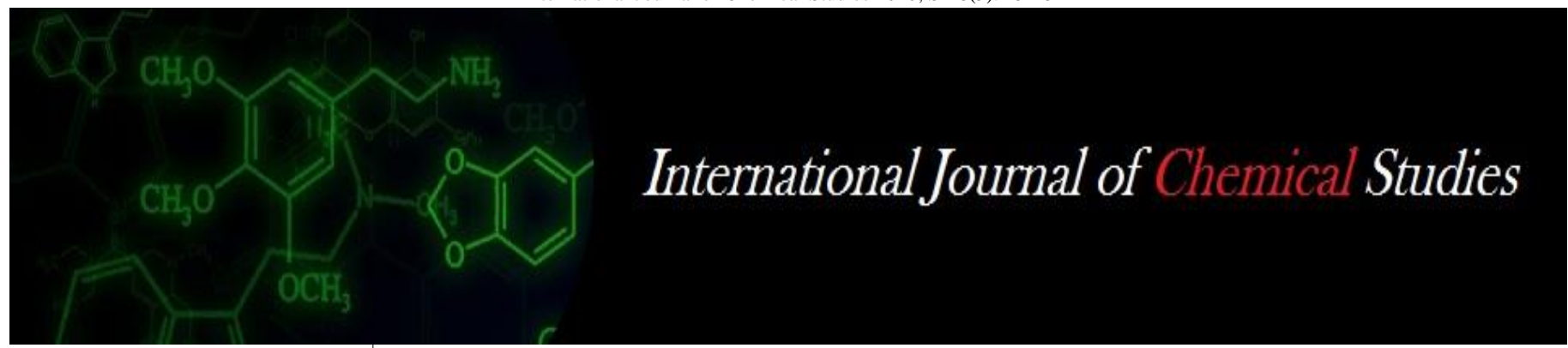

P-ISSN: 2349-8528

E-ISSN: 2321-4902

www.chemijournal.com

IJCS 2020; SP-8(5): 15-18

(C) 2020 IJCS

Received: 15-07-2020

Accepted: 20-08-2020

\section{S Shenbagavalli}

Department of Soil Science and Agricultural Chemistry, AC\&RI, Killikulam, Tamil Nadu, India

\section{T Prabhu}

Krishi Vidyan Kendra,

Nagerkovil, Tamil Nadu, India

S Ponmani

Mother Therasa Agricultural College, Pudukottai, Tamil

Nadu, India

\section{Effect of Fishwaste compost on nutrient content and uptake of black gram}

\section{S Shenbagavalli, T Prabhu and S Ponmani}

\author{
DOI: https://doi.org/10.22271/chemi.2020.v8.i5a.10363
}

\begin{abstract}
The main objective of this study was production of compost from fish waste generated from the seafood processing unit and fish market. The fish waste was acidic in $\mathrm{pH}(6.1)$ with $\mathrm{EC}$ of $3.8 \mathrm{dSm}^{-1}$. The total N, $\mathrm{P}, \mathrm{K}$ of the fish waste was $10.17,0.20$ and $0.74 \%$ respectively. It also had an appreciable amount of organic carbon content $46.22 \%$. The calcium and magnesium content of fish waste were 1.86 and $0.15 \%$ respectively. A compost pile was created using the windrow method. The fish waste compost (FWC) was neutral in $\mathrm{pH}(7.1)$ with low soluble salts $\left(\mathrm{EC}=0.38 \mathrm{dS} \mathrm{m}^{-1}\right)$. It was $28 \%$ of organic carbon content and appreciable amount of $\mathrm{N}(1.6 \%), \mathrm{P}(0.16 \%)$ and $\mathrm{K}(0.21 \%)$. A pot study was conducted to examine the effect of fish waste compost on growth and yield parameters of black gram. Among the different treatment, application of FWC @ 4t/ha (T5) enhance the growth and yield parameters of black gram.
\end{abstract}

Keywords: Fish waste compost, growth parameter, yield parameter, black gram

\section{Introduction}

In India many restaurants specialize in sliced raw fish, and large amounts (approximately 2100 t/day) of fish waste are generated every day. These wastes are dumped in the vicinity of the seafood processing plants and they lead to environmental pollution. Hence ways and means of utilizing these wastes for productive purposes need to be examined. Direct use of fish waste for land manuring has been discouraged primarily due to the obnoxious odour of putrefied fish.

Fish waste can also be converted as fertilizer through acid digestion and solubilisation of fish waste with urea. However, the fertilizer produced deploying the above method showed poor balance among components like N, P and $\mathrm{K}$. The solid wastes of finfish and shell fish in seafood processing plants and the sludge generated in the wastewater treatment plants can both be converted into manure by composting - a bio-conversion process. Fish manure contains NPK and micronutrients are necessary for plant growth. (Chand et al., 2006) ${ }^{[1]}$. In this context, fish waste samples are collected and produced compost and then used for crop growth experiment.

\section{Materials and Methods}

\section{Collection and Characterization of Fish wastes}

Fish wastes were collected from the Fish market and seafood processing unit, Thoothukudi District, which contains head, tail, shells, intestine, fins, dead fishes and etc. The collected fish wastes were cleaned and washed with water to remove dirt and slick. The sample was dried at $60^{\circ} \mathrm{C}$ in oven followed by reduced into fine powder using pestle and mortar. It was sieved using a sieve with $0.2 \mathrm{~mm}$ and stored for further analysis. The aqueous extracts (substrate/water 1:5 v/v) were used to determine the $\mathrm{pH}$, electrical conductivity. After acid digestion with $\mathrm{H}_{2} \mathrm{SO}_{4}$ and $\mathrm{H}_{2} \mathrm{O}_{2} 30 \%$, Ca and $\mathrm{Mg}$ levels were determined by atomic absorption and $\mathrm{Na}$ and $\mathrm{K}$ by emission. Levels of $\mathrm{P}$ were analysed using colorimetry.

The C: $\mathrm{N}$ ratio of the compost were measured by the method followed by Knnunen, et al., $2005^{[3]}$. Moisture was determined by drying the samples in oven at $105{ }^{\circ} \mathrm{C}$ to constant weight (Egan et al., 1997) ${ }^{[2]}$. All parameters were determined in triplicate and the data shown are mean values. The characteristics of fish waste are presented in Table.1. 


\section{Composting of Fish waste}

A compost pile was created using the windrow method. Fish wastes were collected from the Fish market and seafood processing unit, Thoothukudi District, which contains head, tail, shells, intestine, fins, dead fishes and mixed with cowdung. To increase the $\mathrm{C} / \mathrm{N}$ ratio in the composting materials, saw dust (particle size 10- 20mm) from local saw mill was added. These materials were spread in a compost pile $2 \mathrm{~m}$ wide at the base, $1 \mathrm{~m}$ high and $6 \mathrm{~m}$ long, with a total final volume of $10 \mathrm{~m}^{3}$. To avoid nutrient washout, the pile was set on an impermeable base and sheltered above. The proportion of fishwaste, cowdung and saw dust was 1:1:2. The total duration of the composting process was four months. The compost pile was turned weekly during the first two months and every 15 days during the last two months. The temperature and $\mathrm{O}_{2}$ levels were tested weekly to monitor the correct development of the process. Once the compost was considered mature, it was sifted using a 20- mm mesh screen and stored for further studies.

\section{Evaluation of fish waste compost on black gram}

The effect of fishwaste compost on blackgram(Vigna mungo (L).) variety KKM 1 was examined through a pot experiment. The varietal characters of the cultivars are given below.

Table 1: Varietal characteristics of KKM-1 black gram

\begin{tabular}{|c|c|}
\hline Characters & Descriptions \\
\hline Parentage & COBG 643 x VBN 3 \\
\hline Habit & Determinate \\
\hline Maturity duration (Days) & $65-70$ \\
\hline Plant height (cm) & $45-60$ \\
\hline Days to 50\% flowering & 35 \\
\hline Colour of seed & Dull black \\
\hline 100 grain weight $(\mathrm{g})$ & 4.47 \\
\hline Average yield $\left(\mathrm{kg} \mathrm{ha}^{-1}\right)$ & 607 \\
\hline
\end{tabular}

The air dried samples were used in the crop growth experiments. Physical, chemical and biological characteristics of soil were determined as per the standard procedure. The soil collected for the pot culture experimentation i.e., sandy clay loam soil from the garden land of AC \& RI, Killikulam. Mud pots were utilized for this experimentation. Each pot was filled with $15 \mathrm{~kg}$ of soils. The amendments such as RDF and fish waste compost were mixed well with respective pots as per treatment plan. The recommended dose of fertilisers for black gram is 25: 50: $25 \mathrm{~kg}$ of $\mathrm{N}, \mathrm{P}_{2} \mathrm{O}_{5}$ and $\mathrm{K}_{2} \mathrm{O}$ per hectare. The following treatments with three replication each were imposed.

$\mathrm{T}_{1}$-Recommended dose of fertilizer; $\mathrm{T}_{2}-\mathrm{RDF}+\mathrm{FWC}\left(1 \mathrm{t} \mathrm{ha}{ }^{1}\right)$

$\mathrm{T}_{3}-\mathrm{RDF}+\mathrm{FWC}\left(2 \mathrm{tha}^{-1}\right) ; \mathrm{T}_{4}-\mathrm{RDF}+\mathrm{FWC}\left(3 \mathrm{tha}^{-1}\right)$

$\mathrm{T}_{5}-\mathrm{RDF}+\mathrm{FWC}\left(4 \mathrm{t} \mathrm{ha}^{-1}\right) ; \mathrm{T} 6-\mathrm{RDF}+\mathrm{FWC}\left(5 \mathrm{t} \mathrm{ha}^{-1}\right)$

After a week of equilibration, black gram (KKM 1) seeds were sown. After establishment, a single healthy plant was allowed to grow in the pots. Irrigation was given as and when required to maintain optimum moisture condition throughout the experiment. The pots were arranged in a randomized block design. The height of plant, 50\% flowering, Root length, Number of nodules were recorded at vegetative, flowering and harvest stages of the crop. Pods were harvested after maturity and yield was recorded for each pot. Dry matter yield, Number of pods plant ${ }^{-1}$, Number of grains pod $^{-1}$, hundred grain weight, Haulm and grain yield were recorded at harvest stage of the crop.

\section{Results and Discussion}

The fish waste was acidic in $\mathrm{pH}$ (6.1) with $\mathrm{EC}$ of $3.8 \mathrm{dSm}^{-1}$. The total N, P, K of the fish waste was 10.17, 0.20 and $0.79 \%$ respectively. It also had an appreciable amount of organic carbon content $46.22 \%$. The calcium and magnesium content of fish waste were 1.86 and $0.15 \%$ respectively. Saw dust recorded the highest $\mathrm{C}: \mathrm{N}$ ratio of 75:1. The total NPK content of the saw waste is very low. Some important characteristics of the fish waste compost are presented in Table 2. The results revealed that the compost was neutral in $\mathrm{pH}$ (7.1) with low soluble salts $\left(\mathrm{EC}=0.38 \mathrm{dS} \mathrm{m} \mathrm{m}^{-1}\right)$. It was $28 \%$ of organic carbon content and appreciable amount of $\mathrm{N}(1.6 \%), \mathrm{P}$ $(0.16 \%)$ and $\mathrm{K}(0.21 \%)$.

Table 2: Characteristics of raw materials used for composting (on Dry Weight basis)

\begin{tabular}{|c|c|c|c|}
\hline S. No. & Parameters & Fish waste & Saw dust \\
\hline 1. & $\mathrm{pH}(1: 5)$ & $6.1 \pm 0.61$ & $7.5 \pm 0.75$ \\
\hline 2. & $\mathrm{EC}(1: 5)\left(\mathrm{dSm}^{-1}\right)$ & $3.8 \pm 0.38$ & $0.78 \pm 0.08$ \\
\hline 3. & C:N Ratio & $4.5 \pm 0.45$ & $75 \pm 7.50$ \\
\hline 4. & Organic carbon $(\%)$ & $46.2 \pm 4.62$ & $31.5 \pm 3.15$ \\
\hline 5. & Total Nitrogen $(\%)$ & $10.17 \pm 1.02$ & $0.42 \pm 0.04$ \\
\hline 6. & Total Phosphorus (\%) & $0.2 \pm 0.02$ & $0.06 \pm 0.01$ \\
\hline 7. & Total Potassium (\%) & $0.79 \pm 0.08$ & $0.65 \pm 0.07$ \\
\hline 8. & Total Calcium (\%) & $1.86 \pm 0.19$ & $0.31 \pm 0.03$ \\
\hline 9. & Total Magnesium $(\%)$ & $0.15 \pm 0.01$ & $0.29 \pm 0.03$ \\
\hline
\end{tabular}

Mean value \pm Standard deviation

Table 3: Characteristics of final harvested fish waste compost

\begin{tabular}{|c|c|c|}
\hline S. No. & Parameters & Fish waste Compost (FWC) \\
\hline 1. & $\mathrm{pH}(1: 5)$ & $7.1 \pm 0.71$ \\
\hline 2. & EC $(1: 5)\left(\mathrm{dSm}^{-1}\right)$ & $0.38 \pm 0.04$ \\
\hline 3. & C:N Ratio & $17.1 \pm 2.80$ \\
\hline 4. & Organic carbon $(\%)$ & $28 \pm 0.16$ \\
\hline 5. & Total Nitrogen $(\%)$ & $1.6 \pm 0.02$ \\
\hline 6. & Total Phosphorus $(\%)$ & $0.16 \pm 0.02$ \\
\hline 7. & Total Potassium $(\%)$ & $0.21 \pm 1.71$ \\
\hline
\end{tabular}

\section{Effect on nutrient content and uptake of black gram Nitrogen content \&uptake}

A progressive increase in the nitrogen content was documented over control. The $\mathrm{N}$ content in haulm ranged from 0.95 to 1.09 per cent (Table 4). $\mathrm{T}_{5}$ receiving $\mathrm{RDF}+$ FWC @ 4 t/ha recorded the maximum nitrogen content of 1.20 per cent. whereas, the $\mathrm{N}$ content in grain ranged from 1.95 to 2.20 per cent.

Table 4: Effect of FWC on N (\%) content and uptake (mgplant ${ }^{-1}$ ) of black gram

\begin{tabular}{|c|c|c|c|c|}
\hline \multirow{2}{*}{ Treatment } & \multicolumn{2}{|c|}{$\mathrm{N}$ content $(\%)$} & \multicolumn{2}{|c|}{ N uptake (mgplant ${ }^{-1}$} \\
\hline & Grain & Haulm & Grain & Haulm \\
\hline $\mathrm{T}_{1}$ & 1.95 & 0.95 & 42.42 & 61.47 \\
\hline $\mathrm{T}_{2}$ & 2.06 & 0.98 & 46.14 & 65.34 \\
\hline $\mathrm{T}_{3}$ & 2.01 & 0.97 & 44.47 & 63.87 \\
\hline $\mathrm{T}_{4}$ & 2.11 & 1.02 & 53.04 & 73.00 \\
\hline $\mathrm{T}_{5}$ & 2.18 & 1.20 & 65.80 & 103.79 \\
\hline $\mathrm{T}_{6}$ & 2.20 & 1.09 & 58.76 & 85.02 \\
\hline Mean & 2.13 & 1.09 & 58.97 & 87.03 \\
\hline SEd & 0.08 & 0.04 & 2.37 & 3.04 \\
\hline $\mathrm{CD}(0.05)$ & $\mathrm{NS}$ & 0.10 & 4.88 & 6.26 \\
\hline
\end{tabular}

The maximum $\mathrm{N}$ content in grain $(2.20 \%)$ was recorded in $\mathrm{T}_{6}$ (RDF + FWC @5 t/ha). The nitrogen content of black gram was least under control both for haulm $(0.95 \%)$ and grain $(1.95 \%)$. 
Significant impact was noted on the $\mathrm{N}$ uptake by the black gram owing to the integrated application of RDF and FWC. The total $\mathrm{N}$ uptake by the black gram ranged from 42.42 to $58.97 \mathrm{mg} \mathrm{plant}^{-1}$ in grain and 61.47 to $103.79 \mathrm{mg} \mathrm{plant}^{-1}$ in haulm. Among the treatments, $\mathrm{T}_{5}$ recorded the highest $\mathrm{N}$ uptake both in grain (65.80 $\left.\mathrm{mg} \mathrm{plant}^{-1}\right)$ and haulm (103.79 mg plant $^{-1}$ ) respectively.

The lowest uptake of $\mathrm{N}$ (42.42 $\left.\mathrm{mg} \mathrm{plant}^{-1}\right)$ in grain and (61.47 mg plant ${ }^{-1}$ ) in haulm was duly observed with $\mathrm{T}_{1}$ at harvest stage of the crop growth (Table 4).

The application of FWC significantly increased the nutrient availability and enhanced the nutrient uptake in black gram. Different levels of application of FWC increased the nitrogen content in black gram and concurrently accumulated higher $\mathrm{N}$ in plant biomass.

The higher $\mathrm{N}$ availability from the soil through inorganic fertilization, conducive soil condition created by the organics and slow release of nitrogen from the FWC (Manna et al., 2005) might be reason for this higher $\mathrm{N}$ accumulation in black gram. Similar findings were observed.

\section{Phosphorus content \&uptake}

Phosphorus content of black gram was considerably influenced by FWC at harvest stage of crop. It varied from 0.39 to 0.60 per cent in grain and 0.17 to 0.27 per cent in haulm of the black gram.

Table 5: Effect of FWC on P content (\%) and uptake $\left(\right.$ mgplant $\left.^{-1}\right)$ of black gram

\begin{tabular}{|c|c|c|c|c|}
\hline \multirow{2}{*}{ Treatment } & \multicolumn{2}{|c|}{ P content \% } & \multicolumn{2}{c|}{ P uptake (mg plant ${ }^{-1}$ ) } \\
\cline { 2 - 5 } & Grain & Haulm & Grain & Haulm \\
\hline $\mathrm{T}_{1}$ & 0.40 & 0.17 & 8.70 & 11.00 \\
\hline $\mathrm{T}_{2}$ & 0.39 & 0.17 & 8.74 & 11.34 \\
\hline $\mathrm{T}_{3}$ & 0.39 & 0.17 & 8.63 & 11.19 \\
\hline $\mathrm{T}_{4}$ & 0.44 & 0.21 & 11.06 & 15.03 \\
\hline $\mathrm{T}_{5}$ & 0.60 & 0.27 & 17.96 & 23.35 \\
\hline $\mathrm{T}_{6}$ & 0.54 & 0.23 & 14.42 & 17.94 \\
\hline Mean & 0.50 & 0.22 & 14.16 & 18.02 \\
\hline S.Ed & 0.01 & 0.008 & 0.64 & 0.78 \\
\hline $\mathrm{CD}(0.05)$ & 0.03 & 0.017 & 1.32 & 1.61 \\
\hline
\end{tabular}

The phosphorus content in grain was significantly higher $(0.60 \%)$ with the treatments that received RDF and FWC@4 $\mathrm{t} / \mathrm{ha}\left(\mathrm{T}_{5}\right)$ which was followed by $\mathrm{T}_{6}(0.54 \%)$. All these treatments were statistically on par. Similar treat mental effect was observed for $\mathrm{P}$ content in the haulm too. The control displayed minimum $\mathrm{P}$ content of 0.17 per cent in haulm and $0.4 \%$ in grain.

The $\mathrm{P}$ uptake of black gram was ranged from 8.63 to 17.96 $\mathrm{mg}$ of plant ${ }^{-1}$ in grain and 11 to $23.35 \mathrm{mg} \mathrm{plant}^{-1}$ in haulm (Table 5). Among the combinations of treatments, the highest $\mathrm{P}$ uptake in grain was recorded $\left(17.96 \mathrm{mg} \mathrm{plant}^{-1}\right)$ in $\mathrm{T}_{5}$ receiving $\mathrm{RDF}$ and FWC@4 t/ha. The lowest $\mathrm{P}$ uptake in haulm (11 mg plant $\left.{ }^{-1}\right)$ recorded in $\mathrm{T}_{1}$ and grain $(8.63 \mathrm{mg}$ plant $^{-1}$ ) was observed in $\mathrm{T}_{3}$.

Similar trend of nutrient accumulation was observed both for $\mathrm{P}$ and $\mathrm{K}$. The higher $\mathrm{P}$ accumulation in biomass is predominantly due to the supply of $\mathrm{P}$ from the added inorganic fertilizer.

Further, the releases of organic acids from the decomposition of FYM reduce the $\mathrm{P}$ fixation in soil solid, which resulted in enhanced P availability to plants. Wakudkar et al., (2018) observed similar trend in black gram.

\section{Potassium content \& uptake}

The data affirmed that $\mathrm{K}$ content in black gram grains ranged from 1.10 to 1.31 per cent (Table 15). The application RDF with FWC considerably influenced $\mathrm{K}$ content in crop. $\mathrm{T}_{5}$ receiving $\mathrm{RDF}+\mathrm{FWC} @ 4 \mathrm{t} / \mathrm{ha}$ recorded maximum grain $\mathrm{K}$ content $(1.31 \%)$, Similar treatmental effect was observed for haulm $\mathrm{K}$ content too. The lowest $\mathrm{K}$ content in grain recorded $(1.10 \%)$ with $\mathrm{T}_{2}$ and haulm $(0.82 \%)$ in control.

Table 6: Effect of FWC on K content (\%) and uptake (mgplant $\left.{ }^{-1}\right)$ of black gram

\begin{tabular}{|c|c|c|c|c|}
\hline \multirow{2}{*}{ Treatment } & \multicolumn{2}{|c|}{ K content (\%) } & \multicolumn{2}{c|}{ K uptake (mg plant ${ }^{-1}$ ) } \\
\cline { 2 - 5 } & Grain & Haulm & Grain & Haulm \\
\hline $\mathrm{T}_{1}$ & 1.15 & 0.82 & 25.02 & 53.06 \\
\hline $\mathrm{T}_{2}$ & 1.10 & 0.83 & 24.64 & 55.34 \\
\hline $\mathrm{T}_{3}$ & 1.12 & 0.82 & 24.78 & 53.99 \\
\hline $\mathrm{T}_{4}$ & 1.19 & 0.91 & 29.91 & 65.13 \\
\hline $\mathrm{T}_{5}$ & 1.31 & 1.01 & 39.54 & 87.36 \\
\hline $\mathrm{T}_{6}$ & 1.24 & 0.95 & 33.12 & 74.10 \\
\hline Mean & 1.22 & 0.93 & 33.97 & 74.69 \\
\hline S.Ed & 0.05 & 0.03 & 1.38 & 2.26 \\
\hline CD & 0.10 & 0.06 & 2.84 & 4.66 \\
\hline
\end{tabular}

The $\mathrm{K}$ uptake in black gram ranged from 53.06 to $87.36 \mathrm{mg}$ plant $^{-1}$ in haulm of black gram. The highest grain $\mathrm{K}$ uptake of $39.54 \mathrm{mg} \mathrm{plant}^{-1}$ was recorded in treatment combinations of $\mathrm{RDF}+\mathrm{FWC} @ 4 \mathrm{t} / \mathrm{ha}\left(\mathrm{T}_{1}\right)$. This was followed by recommended dose of RDF + FWC@5 t/ha ( $\left.\mathrm{T}_{6}\right)$ with 33.12 $\mathrm{mg}$ plant $^{-1}$. The lowest grain $\mathrm{K}$ uptake in black gram was recorded $24.64 \mathrm{mg}$ plant $^{-1}$ in $\mathrm{T}_{2}$.

The higher biomass $\mathrm{K}$ in black gram is contributed by many factors. Being rich in available potassium, soil supplies sufficient $\mathrm{K}$ from the soil to plant. Further, $\mathrm{K}$ is supplied through $\mathrm{K}$ fertilization, which additionally supplied the $\mathrm{K}$ to plant besides the positive influence of FWC. The findings are in agreement with Navsare et al., (2018) ${ }^{[11]}$.

Increased the levels of application of FWC in soil, enhanced the content and uptake of nutrient in black gram. Compost applied soil easily absorbed and translocated to the plants directly without spending energy for their transport and without any loss in transit, resulted in increased NPK content and uptake by the crop. Similar results were earlier reported by Ravi et al., (2010)

\section{Conclusion}

The seafood processing plant and capture fisheries produce huge amount of solid waste. The waste from fishes are viscera, offal, skin, scales, shells and other body parts are rich in variety of plant nutritive elements and devoid of hazardous contaminants and pathogens. Disposal of solid waste generated from seafood processing plant has always been a problem for seafood processors. The inappropriate disposal of solid fish wastes may result in environmental problems, such as groundwater and surface water pollution through the leaching due to its high nutritive content. These wastes could be converted into eco-friendly compost through bioconversion process. Composting is a biotechnological process by which different microbial communities acted upon complex organic matter and convert it into simpler nutrients. Composting of fish waste is a relatively new, practical and an environmentally sound alternative to fish waste disposal. It is economical, fairly odourless and a biologically beneficial practice for seafood operations. 


\section{References}

1. Chand S, M Anwar, DD Patra. Influence of long-term application of organic and inorganic fertilizer to build up soil fertility and nutrient uptake in mint-mustard cropping sequence. Commun. Soil Sci. Plant Anal. 2006; 37:63-76.

2. Egan H, RS Krik, R Sawyer. Pearsons'chemical analysis of foods. 9th ed., Longman, London, 1997, 634.

3. RE Kinnunen, MC Gould, P Cambier. Composting Commercial Fish Processing Waste from Fish Caught in the Michigan Waters of the Great Lakes, Michigan State University Extension, USA, 2005.

4. Shewry PR, NG Halford. Cereal seed storage proteins: structures, properties and role in grain utilization. Journal of experimental botany. 2002; 53(370):947-958.

5. Amruta N, J Maruthi, G Sarika, C Deepika. Effect of integrated nutrient management and spacing on growth and yield parameters of black gram cv. LBG-625 (Rashmi). The Bioscan. 2015; 10(1):193-198.

6. Marimuthu S, U Surendran. Effect of nutrients and plant growth regulators on growth and yield of black gram in sandy loam soils of Cauvery new delta zone, India. Cogent Food \& Agriculture. 2015; 1(1):1010415.

7. Vidyashree N. Isolation and characterization of zinc solubilizing bacteria from stone quarry dust powder. International Journal of Agriculture Sciences, 2016. ISSN: 0975-3710.

8. Ramesh A, SK Sharma, MP Sharma, N Yadav, OP Joshi. Inoculation of zinc solubilizing Bacillus aryabhattai strains for improved growth, mobilization and biofortification of zinc in soybean and wheat cultivated in Vertisols of central India. Applied Soil Ecology. 2014; 73:87-96.

9. Goteti PK, LDA Emmanuel, S Desai, MHA Shaik. Prospective zinc solubilising bacteria for enhanced nutrient uptake and growth promotion in maize (Zea mays L.). International journal of microbiology, 2013.

10. Khande R, SK Sharma, A Ramesh, MP Sharma. Zinc solubilizing Bacillus strains that modulate growth, yield and zinc biofortification of soybean and wheat. Rhizosphere. 2017; 4:126-138.

11. Navsare R, S Mane, S Supekar. Effect of potassium and zinc solubilizing microorganism on growth, yield and quality of mungbean. IJCS. 2018; 6(1):1996-2000.

12. Raut A, A Durgude, A Kadlag. "Effect of zinc solubilizing bacteria on zinc use efficiency and yield of summer groundnut grown in Entisol. IJCS. 2019; 7(1):1710-1713.

13. Selvakumar G, S Reetha, P Thamizhiniyan. Response of biofertilizers on growth, yield attributes and associated protein profiling changes of blackgram (Vigna mungo L. Hepper). World applied sciences journal. 2012; 16(10):1368-1374.

14. Malewar G, M Mangnale, V Malewar. Chemical composition and quality of mung genotypes as influenced by zinc fertilization. Legume Research. 1990; 13(2):5964.

15. Kumar PS, SA Geetha, P Savithri, R Jagadeeswaran, K Ragunath. Effect of $\mathrm{Zn}$ enriched organic manures and zinc solubilizer application on the yield, curcumin content and nutrient status of soil under turmeric cultivation. Journal of Applied Horticulture. 2004; $6(2): 82-86$

16. Newaj M, MS Hossain, MN Islam, M Anam, A Haque. Effect of Indoleacetic Acid (IAA) on Yield of Mungbean
(Vignaradiata L.). Pakistan J of Biol. Sci. 2002; 5:897899.

17. El Karamany MF, MS Sadak, BA Bakry. Improving quality and quantity of mungbean plant via foliar application of plant growth regulators in sandy soil conditions. Bulletin of the National Research Centre. 2019; 43(1):61. 